\title{
Continuous Positive Airway Pressure Treatment: Effect on Serum Lipids in Patients with Obstructive Sleep Apnoea
}

\author{
Vassileios Michailidis ${ }^{1}$, Paschalis Steiropoulos ${ }^{1, *}$, Evangelia Nena ${ }^{1}$, Nikolaos Papanas ${ }^{2}$, \\ Efstratios Maltezos ${ }^{2}$ and Demosthenes Bouros ${ }^{1}$
}

\author{
${ }^{1}$ Department of Pneumonology, Democritus University of Thrace, Greece; ${ }^{2}$ Second Department of Internal Medicine, \\ Democritus University of Thrace, Greece
}

\begin{abstract}
Obstructive Sleep Apnoea (OSA) is a common disorder in adults. Its hallmark is repetitive episodes of partial or complete obstruction of the upper airway during sleep associated with increasing respiratory efforts. This leads to oxyhaemoglobin desaturation, sleep fragmentation, and daytime symptoms, mainly excessive sleepiness. Accumulating evidence suggests that intermittent hypoxia and oxyhaemoglobin desaturation may, irrespective of obesity, lead to elevation of serum lipids even in non-dyslipidaemic OSA patients. Continuous Positive Airway Pressure (CPAP) is the treatment of choice for OSA, since it eliminates upper airway collapse during sleep and improves sleep fragmentation, daytime symptoms and quality of life. Moreover, it has been proposed that the amelioration of breathing disturbances during sleep can improve several markers of the lipid profile, such as total cholesterol, triglycerides, low-density lipoprotein cholesterol, high-density lipoprotein cholesterol as well as apolipoproteins A, B and C. Indeed, some studies have reported improvements in these parameters especially in CPAP adherent patients. However, other studies failed to confirm this beneficial effect. The present article reviews the issue whether CPAP treatment exerts a beneficial effect on lipids.
\end{abstract}

Keywords: Continuous positive airway pressure, cholesterol, lipid profile, obstructive sleep apnoea, triglycerides.

\section{INTRODUCTION}

Obstructive Sleep Apnoea (OSA) is a common disorder, affecting approximately $4 \%$ of adult men and $2 \%$ of adult women in the general population [1]. OSA is being increasingly recognised as a cause of morbidity and mortality [1].

OSA is characterised by repeated episodes of complete or partial obstruction of the upper airway during sleep. Airway obstruction increases respiratory effort, and leads to intermittent arterial oxygen desaturation, systemic and pulmonary arterial blood pressure alterations, and sleep fragmentation [1]. Main symptoms include nocturnal respiratory pauses, interrupted by loud snoring and excessive daytime sleepiness [1]. The gold standard for diagnosis is polysomnography, a simultaneous meticulous recording of multiple physiologic parameters, namely electroencephalogram, electrooculogram, electromyogram, oronasal airflow, chest wall and abdominal motion, body position, snoring, electrocardiogram and oxyhaemoglobin saturation [2].

The definitions of sleep-related respiratory disturbances have been clarified in recent years, particularly apnoea, hypopnoea and respiratory effort-related arousals (RERAs) [2]. Apnoea is the complete cessation of airflow lasting at least $10 \mathrm{sec}$; hypopnoea is a discernible fall in airflow

*Address correspondence to this author at the Medical School, Democritus University of Thrace, Department of Pneumonology, University Hospital of Alexandroupolis, 68100 Alexandroupolis, Greece;

Tel:/Fax: +302551075333; E-mail: pstirop@med.duth.gr lasting at least $10 \mathrm{sec}$ accompanied by a decrease in oxygen saturation of at least $3 \%$ or by an EEG-recorded arousal; RERA refers to increasing respiratory effort, leading to an arousal from sleep, which does not meet the criteria for apnoea or hypopnoea [2]. Apnoea-hypopnoea index (AHI) is the total number of apnoeas and hypopnoeas per hour of sleep, and respiratory disturbance index (RDI) is the total number of events (e.g. apnoeas, hypopnoeas and RERAs) per hour of sleep [2]. RDI is generally higher than AHI, because the former includes RERAs, whereas the latter does not [2].

OSA is associated with increased cardiovascular morbidity and mortality [1, 2]. Although it was previously assumed that this was due to its relation with obesity, recent data suggest that OSA is independently associated with the cardiovascular risk factors that comprise metabolic syndrome (MetS); one of them being dyslipidaemia $[1,2]$.

Continuous Positive Airway Pressure (CPAP) is the treatment of choice for OSA [3]. It was proven to be efficacious in eliminating obstructive respiratory events during sleep, ameliorating sleep architecture, improving daytime sleepiness and quality of life [4,5], and reducing serum levels of cardiovascular risk factors, such as total cholesterol [6] and markers of systemic inflammation [7]. Unfortunately, patient adherence to CPAP treatment remains suboptimal and its use during sleep time shows substantial variation $[8,9]$.

Not only is CPAP the established treatment for OSA, but it may also have a favourable effect on the lipid profile in such patients. It has been postulated that CPAP use ameliorates in- 
termittent hypoxia and reduces sympathetic nerve activity [10], which may account for an improved lipid profile. Furthermore, effective treatment of OSA may result to increased physical activity and a reduction of hypersomnolence during the day [11]. It is well known that physical activity can also improve serum lipid levels [12]. This additional therapeutic benefit is attracting considerable interest, but it is still under debate. Findings from numerous studies on the effect of CPAP treatment on lipids in OSA populations have been rather conflicting. This can be attributed to differences between the studied populations (i.e. dyslipidaemic, non-dyslipidaemic, obese or non-obese patients), the primary outcomes, the period of CPAP application (ranging between 1 month and 1 year) and patient adherence to CPAP use.

The present article provides a review of the current evidence whether CPAP treatment exerts a beneficial effect on lipid profile.

\section{METHODOLOGY: SEARCH STRATEGY AND ENDPOINTS}

Our search strategy was based on the PubMed, Medscape, Embase and Google scholar databases up to May 2011 using combinations of the following keywords: Continuous positive airway pressure; lipid profile; dyslipidaemia; cholesterol; obstructive sleep apnoea. It included all types of articles (randomised controlled trials, original studies, review articles) written in English.

Treatment effect was assessed by evaluating the impact on serum lipids. Lipid parameters included cholesterol, triglycerides (TGs), low-density lipoprotein cholesterol (LDL-C), high-density lipoprotein cholesterol (HDL-C), apolipoproteins (apo) A, B and C. In many cases, lipid measurements were determined by enzymatic methods using commercial kits. Determination of cholesterol was performed after enzymatic hydrolysis and oxidation. LDL$\mathrm{C}$ was derived using the Friedewald equation.

\section{ASSOCIATION OF OSA WITH DYSLIPIDAEMIA}

The link between OSA and lipid metabolism still remains to be defined. The repetitive episodes of upper airway obstruction that are characteristic of OSA result in intermittent hypoxia and large swings in intra-thoracic pressure that trigger autonomic responses, and sympathetic overactivity has been reported in patients with OSA [2]. There is a direct link between the adrenergic system and lipid levels and the chronic elevated sympathetic activity in OSA patients may lower HDL-C and increase serum TG levels [13, 14]. Metabolic and atherosclerotic changes have been previously shown in mice exposed to chronic intermittent hypoxia (IH) [15]. It has been demonstrated in mice that IH induces hypercholesterolaemia by increasing lipoprotein secretion via upregulation of a key hepatic enzyme, stearoyl-coenzyme A desaturase-1(SCD-1) [16-18].

The association between OSA and lipid profile has been studied with conflicting results. Some findings suggest that OSA is independently associated with lipid abnormalities, while others show that dyslipidaemia is associated with obesity and not directly to OSA.
In a cross-sectional analysis of a selected group of males with and without OSA, Kono et al. [19] reported that OSA was associated with dyslipidaemia in non-obese patients, independent of visceral fat obesity. Borgel et al. [20] demonstrated an influence of OSA on HDL-C levels. In their study, an independent association was found between the change in $\mathrm{AHI}$ and the change in HDL-C or triglycerides, respectively. Can et al. [21] found that OSA is associated with increased lipid levels. Total cholesterol, LDL-C, TGs and apolipoprotein B values were increased in patients with OSA compared with controls (without OSA, p <0.05). Iesato et al. [22] reported that circulating lipoprotein lipase concentrations, which are negatively correlated with TG concentrations and positively correlated with HDL-C concentrations, were lower in OSA patients compared with those in non-OSA patients. Tan et al. [23] demonstrated that OSA subjects had greater degree of HDL dysfunction $(\mathrm{p}<0.01)$ and increased oxidised LDL levels $(\mathrm{p}<0.05)$ compared with controls and that AHI was the main determinant of HDL dysfunction in OSA. In the Sleep Heart Health Study (SHHS), there was an independent association between the severity of OSA and HDL-C levels in females only, while there was only a minor but significant association with total cholesterol levels in males. These findings were evident in the age group <65 years after adjustment for co-variates [24].

Gruber et al. [25] reported that OSA is associated with MetS independently of obesity, predominantly due to increased TG levels. Zgierska et al. [26] found an independent, positive correlation $(\mathrm{p}<0.05)$ between TG levels and AHI, suggesting that OSA increases the risk of coronary artery disease by increasing plasma TGs, independently of obesity. Limited case-control data suggest that OSA is associated with a pattern of dyslipidaemia typical of the MetS. Coughlin et al. [27] demonstrated that OSA was independently associated with decreased HDL-C, increased cholesterol:HDL-C ratio and higher TG concentrations. Previous studies have also demonstrated that OSA is independently associated with dyslipidaemia $[28,29]$.

On the other hand, McArdle et al. [30] reported an increase in LDL-C and total cholesterol among patients with OSA, a result partially explained by the presence of central obesity in these patients. Furthermore, Sharma et al. [31] found that OSA has no independent association with lipid abnormalities and that obesity was the major determinant of metabolic abnormalities in obese subjects with OSA.

\section{EFFECT OF CPAP ON SERUM LIPIDS: POSITIVE STUDIES}

Several studies have provided evidence for the benefits of CPAP treatment on the lipid profile of OSA patients (Table 1). Chin et al. [32] studied the changes in lipid levels before and after 8 months of CPAP treatment in 22 OSA patients in correlation with weight reduction, defined as BMI change $>1 \mathrm{~kg} / \mathrm{m}^{2}$ from baseline. In the group without body weight reduction $(\mathrm{n}=13)$, significant changes in HDL-C $(\mathrm{p}=0.013)$ and LDL-C $(\mathrm{p}=0.046)$ levels occurred. In the group with body weight reduction $(n=9)$, there was a significant improvement in HDL-C $(\mathrm{p}=0.025)$, LDL-C $(\mathrm{p}=0.011)$, TGs $(\mathrm{p}=0.028)$, Apo A-II $(\mathrm{p}=0.008)$ and Apo C-II ( $\mathrm{p}=0.021)$ serum levels [32].

Ip et al. [29] examined the effect of 6-month CPAP treatment on leptin, TGs and cholesterol levels among patients with 
Table 1. Effect of CPAP Treatment on Serum Lipids: Positive Studies

\begin{tabular}{|c|c|c|c|c|c|c|c|c|c|c|}
\hline Author, Year & $\begin{array}{c}\text { No of } \\
\text { patients }\end{array}$ & $\begin{array}{l}\text { Control Group/ } \\
\text { Adherence to } \\
\text { CPAP (h/night) }\end{array}$ & $\begin{array}{c}\text { Baseline Lipid } \\
\text { Profile }\end{array}$ & $\begin{array}{c}\text { Age } \\
\text { (Years) }\end{array}$ & $\begin{array}{c}\text { BMI } \\
\left(\mathrm{Kg} / \mathbf{m}^{2}\right)\end{array}$ & $\mathbf{A H I}(/ \mathbf{h})$ & ESS & Duration & Methods & Results \\
\hline $\begin{array}{c}\text { Chin et al. } \\
1999\end{array}$ & 22 & $\begin{array}{l}\text { No body weight } \\
\text { reduction }(n=13) \text {, } \\
\text { body weight } \\
\text { reduction }(n=9)\end{array}$ & & $\begin{array}{l}\text { NBWR: } \\
46.2 \pm 3.7 \\
\text { BWR: } \\
50.8 \pm 3.7\end{array}$ & $\begin{array}{c}\text { NBWR: } \\
28.5 \pm 0.8, \\
\text { BWR: } 31.2 \pm 1.7\end{array}$ & $\begin{array}{l}\text { NBWR: } \\
52.7 \pm 5 \\
\text { BWR: } \\
63.5 \pm 5.8\end{array}$ & & 8 months & $\begin{array}{c}\text { TC, } \\
\text { triglycerides, } \\
\text { HDL-C, } \\
\text { LDL-C, apoA-I, } \\
\text { apoA-II, apoB, } \\
\text { apoC-II, } \\
\text { apoC-III, apoE }\end{array}$ & $\begin{array}{c}\text { NBWR: } \\
\text { improvement } \\
\text { in HDL-C and } \\
\text { LDL-C } \\
\text { BWR: improve- } \\
\text { ment in } \\
\text { triglycerides, } \\
\text { HDL-C, LDL-C, } \\
\text { apoA-II, apoC-II }\end{array}$ \\
\hline $\begin{array}{l}\text { Ip et al. } \\
2000\end{array}$ & 60 & Yes & & $\begin{array}{c}\text { OSA: } \\
43.6 \pm 10.1 \\
\text { control: } \\
41.9 \pm 10.4\end{array}$ & $\begin{array}{c}\text { OSA: } \\
27 \pm 2.9 \\
\text { control: } \\
26.5 \pm 2.1\end{array}$ & $\begin{array}{l}35.7 \pm 18 \\
1.8 \pm 1.9\end{array}$ & & 6 months & $\begin{array}{c}\text { TC, } \\
\text { triglycerides, } \\
\text { HDL-C, LDL- } \\
\text { C, TC/HDL-C } \\
\text { ratio }\end{array}$ & $\begin{array}{c}\text { Decrease in } \\
\text { triglycerides } \\
\text { levels after CPAP } \\
\text { treatment }\end{array}$ \\
\hline $\begin{array}{l}\text { Buechner } \\
\text { et al. } \\
2001\end{array}$ & 95 & $\begin{array}{l}\text { Effective treated } \\
\text { group/ ineffective } \\
\text { treated group }\end{array}$ & $\begin{array}{c}\text { LDL-C levels } \geq \\
130 \mathrm{mg} / \mathrm{dl}\end{array}$ & $56.6 \pm 9.5$ & & & & 6 months & $\begin{array}{c}\text { TC, } \\
\text { triglycerides, } \\
\text { HDL-C, } \\
\text { LDL-C, apoB, } \\
\text { and lipoprotein } \\
\text { (a) levels }\end{array}$ & $\begin{array}{l}\text { Decrease in TC } \\
\text { and LDL-C in } \\
\text { effective treated } \\
\text { group }\end{array}$ \\
\hline $\begin{array}{l}\text { Robinson } \\
\text { et al. } \\
2004\end{array}$ & 220 & $\begin{array}{c}\text { Yes/ } \\
\text { Subtherapeutic } \\
\text { CPAP } 4.1 \pm 2.4 \text {, } \\
\text { therapeutic CPAP } \\
5.0 \pm 1.9\end{array}$ & $\begin{array}{c}\text { Mean baseline } \\
\text { levels of TC } \\
\text { within the } \\
\text { normal range in } \\
\text { both groups }\end{array}$ & $\begin{array}{l}49.1 \pm 10.3 \\
49.7 \pm 10.3\end{array}$ & $\begin{array}{l}35.9 \pm 6.3 \\
35.6 \pm 7.6\end{array}$ & $\begin{array}{c}\text { Oxygen } \\
\text { saturation } \\
\text { dips } 4 \% \\
\text { (per hour of } \\
\text { sleep): } \\
38.5 \pm 20.3 \\
38.9 \pm 21.1\end{array}$ & $\begin{array}{l}16.2 \pm 3.3 \\
16.3 \pm 3.3\end{array}$ & 1 year & $\begin{array}{c}\mathrm{TC}, \\
\text { triglycerides }\end{array}$ & $\begin{array}{l}\text { Reduction in TC } \\
\text { in therapeutic } \\
\text { CPAP group }\end{array}$ \\
\hline $\begin{array}{l}\text { Borgel et al. } \\
2006\end{array}$ & 127 & & $\begin{array}{l}\text { 9.4\% were under } \\
\text { lipid lowering } \\
\text { medication }\end{array}$ & $55.7 \pm 10.6$ & $31.6 \pm 5.9$ & $32.9 \pm .21 .5$ & & 6 months & $\begin{array}{c}\text { TC, } \\
\text { triglycerides, } \\
\text { HDL-C, } \\
\text { LDL-C }\end{array}$ & $\begin{array}{l}\text { Improvement in } \\
\text { TC, triglycerides, } \\
\text { HDL-C, LDL-C } \\
\text { levels in patients } \\
\text { with initial } \\
\text { abnormal } \\
\text { lipids levels }\end{array}$ \\
\hline $\begin{array}{c}\text { Dorkova et al. } \\
2008\end{array}$ & 32 & $\begin{array}{l}\mathrm{No} / \\
\text { Good adherence } \\
\text { group }(5.1 \pm 1.2) \\
\text { Poor adherence } \\
\text { group }(1.9 \pm 1.1)\end{array}$ & & $53.7 \pm 9.6$ & $35.1 \pm 6.1$ & $64 \pm 20.8$ & $13.3 \pm 4.6$ & 8 weeks & $\begin{array}{c}\text { TC } \\
\text { triglycerides, } \\
\text { HDL-C ,LDL- } \\
\text { C, apoA-I, apoB }\end{array}$ & $\begin{array}{l}\text { Reduction in TC } \\
\text { and apoB in the } \\
\text { good adherence } \\
\text { group }\end{array}$ \\
\hline $\begin{array}{l}\text { Barcelo et al. } \\
2008\end{array}$ & 44 & $\begin{array}{c}\text { Yes/ } \\
\text { OSA with EDS } \\
(\mathrm{n}=22), \text { OSA } \\
\text { without EDS } \\
(\mathrm{n}=22)\end{array}$ & & & & & & 3 months & $\begin{array}{c}\mathrm{TC}, \\
\text { triglycerides }\end{array}$ & $\begin{array}{l}\text { Reduction in TC } \\
\text { in patients with } \\
\text { EDS }\end{array}$ \\
\hline $\begin{array}{c}\text { Oktay et al. } \\
2009\end{array}$ & 20 & No & & $50 \pm 7.74$ & & & & 1 year & & $\begin{array}{l}\text { Increase in } \\
\text { HDL-C }\end{array}$ \\
\hline $\begin{array}{c}\text { Cuhadaroglu } \\
\text { et al. } \\
2009\end{array}$ & 31 & $\begin{array}{c}\text { Mean CPAP use } \\
>4 \mathrm{~h} / \text { night }\end{array}$ & & $\begin{array}{l}\text { Range: } 28- \\
\quad 76\end{array}$ & $32.3 \pm 4.7$ & $\begin{array}{c}\text { Range 16- } \\
90\end{array}$ & $11.3 \pm 5.7$ & 8 weeks & $\begin{array}{c}\text { TC, } \\
\text { triglycerides, } \\
\text { HDL-C, LDL- } \\
\text { C, VLDL-C }\end{array}$ & $\begin{array}{l}\text { Reduction in TC } \\
\text { and LDL-C }\end{array}$ \\
\hline
\end{tabular}


Table 1. contd....

\begin{tabular}{|c|c|c|c|c|c|c|c|c|}
\hline Author, Year & $\begin{array}{c}\text { No of } \\
\text { patients }\end{array}$ & $\begin{array}{c}\text { Control Group/ } \\
\text { Adherence to } \\
\text { CPAP (h/night) }\end{array}$ & $\begin{array}{c}\text { Baseline Lipid } \\
\text { Profile }\end{array}$ & $\begin{array}{c}\text { Age } \\
\text { (Years) }\end{array}$ & $\begin{array}{c}\text { BMI } \\
\left(\mathbf{K g} / \mathbf{m}^{2}\right)\end{array}$ & AHI/h) & ESS & Duration \\
\hline \hline Steiropoulos \\
et al.
\end{tabular}

Abbreviations: $\mathrm{AHI}=$ apnea-hypopnea index, apo = apolipoprotein, $\mathrm{BMI}=$ body mass index, $\mathrm{CPAP}=$ continuous positive airway pressure, EDS $=$ excessive daytime sleepiness, HDL-C=high density lipoprotein cholesterol, LDL-C=low density lipoprotein cholesterol, TC = total cholesterol.

severe OSA (AHI: 35.7 \pm 18 ). They found a significant decrease in serum leptin $(p=0.012)$ and TGs $(p=0.017)$, while no significant change was observed in serum cholesterol.

Buechner et al. [33] studied the treatment effect on lipid levels in patients with OSA. They demonstrated a significant decrease in total cholesterol and LDL-C levels $(\mathrm{p}<0.001)$ after 6 months, but this occurred only in patients effectively treated with CPAP.

In a meta-analysis of 2 randomised placebo-controlled trials in OSA patients, Robinson et al. [34] compared the effect of therapeutic and subtherapeutic CPAP treatment on cholesterol and TGs. Despite the short treatment duration (1 month), there was a significant reduction in total cholesterol levels among patients receiving therapeutic CPAP $(\mathrm{p}=0.001)$, whereas no such change was observed among those receiving subtherapeutic CPAP. No significant changes were observed in serum levels of TGs in either group [34].

In a large population-based study, Borgel et al. [20] demonstrated a small but significant increase in HDL-C $(p<0.013)$ after 6 months of CPAP therapy in 127 OSA patients (AHI: 32.9 \pm 21.5 ). Furthermore, the authors observed significant improvements in serum levels of HDL-C $(p<0.001)$, LDL-C $(p<0.001)$, total cholesterol $(\mathrm{p}=0.001)$ and TGs $(\mathrm{p}=0.01)$ in OSA patients with baseline abnormal lipid/lipoprotein serum levels [20].

Dorkova et al. [35] examined the effect of 8-week CPAP therapy in 32 patients with severe OSA and MetS, as well as the role of adherence to therapy. Adequate adherence was defined as use of CPAP more than 4h/night, while poor adherence was defined as use of CPAP for less than $4 \mathrm{~h} /$ night. They observed a significant reduction in total cholesterol $(\mathrm{p}=0.02)$ and apoB $(\mathrm{p}=0.009)$ in patients with adequate adherence to treatment [35]. Conversely, no significant changes were noted in the noncompliant group.

Barcelo et al. [36] studied 35 patients with OSA \pm excessive daytime sleepiness (EDS) who underwent CPAP treatment for 3 months. They found a significant decrease in cholesterol only in patients with EDS.
In an observational prospective cohort study, Oktay et al. [37] investigated the effect of 1-year CPAP treatment in patients with OSA. No significant difference was found in TG levels after treatment. However, a significant increase was observed in HDL-C ( $\mathrm{p}=0.001)$ [37].

The study of Cuhadaroglu et al. [38], examining the effects of 8 weeks of CPAP therapy, reported a reduction in total cholesterol $(\mathrm{p}<0.05)$ and LDL-C $(\mathrm{p}<0.05)$ in 31 patients with moderate to severe OSA who used CPAP for $>4 \mathrm{~h} /$ night.

Finally, in a study from our centre [6], we examined the effect of compliance to CPAP therapy on serum lipids, demonstrating significant improvements in total cholesterol $(\mathrm{p}=0.021)$, total cholesterol/ HDL-C ratio $(\mathrm{p}=0.018)$ and ApoB/ ApoA-I ratio $(\mathrm{p}=0.021)$ after 6 months [6]. Again, reductions were only achieved in patients who were adherent to CPAP use ( $\geq 4$ h use per night).

\section{EFFECT OF CPAP ON SERUM LIPIDS: NEGATIVE STUDIES}

There are several studies suggesting that CPAP treatment does not improve serum lipids (Table 2). Davies et al. [39] compared serum lipids of 15 not previously treated OSA patients and 18 snorers, in order to examine their association with coronary heart disease. OSA patients received CPAP treatment for more than 3 months. Levels of total cholesterol, TGs, very low density lipoprotein cholesterol (VLDL-C), LDL-C, and HDL-C of snorers and OSA patients were measured before and after CPAP treatment. There was no significant difference in the abovementioned serum lipids when OSA patients before treatment and snorers were compared [39]. Furthermore, no change was observed in OSA after CPAP treatment [39].

In another study in 43 OSA patients [40], it was reported that cholesterol levels were neither elevated at baseline compared with controls nor reduced by CPAP.

Al-Shaer et al. [41] compared the changes in lipid profile between OSA patients receiving CPAP treatment $(n=34)$ and those not receiving CPAP $(n=28)$. After $126 \pm 33.7$ days of follow-up, there was no change in lipid levels of the CPAP group, nor any difference between the 2 groups. 
Table 2. Effect of CPAP Treatment on Serum Lipids: Negative Studies

\begin{tabular}{|c|c|c|c|c|c|c|c|c|c|c|}
\hline $\begin{array}{l}\text { Author, } \\
\text { Year }\end{array}$ & $\begin{array}{c}\text { No of } \\
\text { Patients }\end{array}$ & $\begin{array}{l}\text { Control Group/ } \\
\text { Adherence to } \\
\text { CPAP (h/night) }\end{array}$ & $\begin{array}{l}\text { Baseline Lipid } \\
\text { Profile }\end{array}$ & $\begin{array}{c}\text { Age } \\
\text { (Years) }\end{array}$ & $\begin{array}{c}\text { BMI } \\
\left(\mathbf{K g} / \mathbf{m}^{2}\right)\end{array}$ & AHI (/h) & ESS & Duration & Methods & Results \\
\hline $\begin{array}{c}\text { Davies } \\
\text { et al. } 1994\end{array}$ & 10 & Yes & $\begin{array}{c}\text { No } \\
\text { dyslipidaemia }\end{array}$ & & & & & $>3$ months & $\begin{array}{c}\mathrm{TC}, \\
\text { triglycerides }\end{array}$ & No difference \\
\hline $\begin{array}{l}\text { Barcelo } \\
\text { et al. } \\
2004\end{array}$ & 43 & Yes & & & & & & & $\mathrm{TC}$ & No difference \\
\hline $\begin{array}{l}\text { Al-Shaer } \\
\text { et al. } \\
2005\end{array}$ & 62 & $\mathrm{CPAP}(\mathrm{n}=34)$ & & & & 37.65 & & $\begin{array}{c}126.2 \pm 33.7 \\
\text { days }\end{array}$ & $\begin{array}{c}\mathrm{TC}, \\
\text { triglycerides }\end{array}$ & $\begin{array}{c}\text { No difference } \\
\text { between the } \\
\text { two groups, } \\
\text { before and } \\
\text { after CPAP }\end{array}$ \\
\hline $\begin{array}{l}\text { Lattimore } \\
\text { et al. } \\
2006\end{array}$ & 10 & No & $\begin{array}{c}\mathrm{TC}, \text { LDL-C } \\
\text { and HDL-C } \\
\text { within normal } \\
\text { limits }\end{array}$ & $49 \pm 8$ & $\begin{array}{c}31 \\
\text { (range } \\
24-41)\end{array}$ & $\begin{array}{c}39 \\
\text { (range } \\
15-104)\end{array}$ & & 3 months & $\mathrm{TC}$ & $\begin{array}{c}\text { No difference } \\
\text { before and } \\
\text { after CPAP } \\
\text { treatment }\end{array}$ \\
\hline $\begin{array}{c}\text { Kitahara } \\
\text { et al. } \\
2006\end{array}$ & 17 & No & & & & & $8.6 \pm 1$ & 4 months & $\mathrm{TC}$ & $\begin{array}{c}\text { No difference } \\
\text { before and } \\
\text { after CPAP } \\
\text { treatment }\end{array}$ \\
\hline $\begin{array}{l}\text { West et al. } \\
2007\end{array}$ & 42 & $\begin{array}{c}\text { Therapeutic } \\
\text { CPAP }(\mathrm{n}=20) \\
\text { Placebo CPAP } \\
(\mathrm{n}=22)\end{array}$ & & $\begin{array}{c}58 \\
\text { (range } \\
29-74) \\
55 \\
\text { (range } \\
24-46)\end{array}$ & $\begin{array}{c}36.6 \\
\text { (range } \\
26.2-49.2) \\
36.8 \\
(\text { range } \\
29.2-47.1)\end{array}$ & & $\begin{array}{l}14.7 \pm 3.5 \\
13.6 \pm 3.5\end{array}$ & 3 months & $\begin{array}{c}\text { TC, } \\
\text { triglycerides, } \\
\text { HDL-C }\end{array}$ & $\begin{array}{c}\text { No difference } \\
\text { before and } \\
\text { after CPAP } \\
\text { treatment }\end{array}$ \\
\hline $\begin{array}{l}\text { Drager } \\
\text { et al. } \\
2007\end{array}$ & 24 & Yes & $\begin{array}{c}\text { Mild } \\
\text { dyslipidaemia, } \\
\text { borderline high } \\
\text { levels of LDL-C }\end{array}$ & $\begin{array}{c}\text { Control: } \\
47 \pm 6 \\
\text { CPAP: } \\
44 \pm 7\end{array}$ & $\begin{array}{c}\text { Control: } \\
29.7 \pm 2.9 \\
\text { CPAP: } \\
29.9 \pm 3\end{array}$ & $\begin{array}{c}\text { Control: } \\
62 \pm 22 \\
\text { CPAP: } \\
56 \pm 22\end{array}$ & $\begin{array}{c}\text { Control: } \\
13 \pm 5 \\
\text { CPAP: } \\
14 \pm 4\end{array}$ & 4 months & $\begin{array}{c}\text { TC, } \\
\text { triglycerides, } \\
\text { HDL-C, } \\
\text { LDL-C }\end{array}$ & $\begin{array}{c}\text { No difference } \\
\text { before and } \\
\text { after CPAP } \\
\text { treatment }\end{array}$ \\
\hline $\begin{array}{l}\text { Coughlin } \\
\text { et al. } \\
2007\end{array}$ & 34 & $\begin{array}{c}\text { Crossover trial: } \\
\text { Sham CPAP } \\
2.6(0-7.5) \\
\text { Therapeutic } \\
\text { CPAP } \\
3.9(0-7.4)\end{array}$ & & $49 \pm 8.3$ & $36.1 \pm 7.6$ & $\begin{array}{c}39.7 \pm 13 \\
8\end{array}$ & $13.8 \pm 4.9$ & 6 weeks & $\begin{array}{c}\text { TC, } \\
\text { triglycerides, } \\
\text { HDL-C, } \\
\text { LDL-C }\end{array}$ & $\begin{array}{c}\text { No difference } \\
\text { before and } \\
\text { after CPAP } \\
\text { treatment }\end{array}$ \\
\hline $\begin{array}{l}\text { Li et al. } \\
2009\end{array}$ & 20 & No & & & & $\begin{array}{c}54.25 \pm 22 \\
.78\end{array}$ & & 90 days & $\begin{array}{c}\text { TC, } \\
\text { triglycerides, } \\
\text { HDL-C, } \\
\text { LDL-C }\end{array}$ & $\begin{array}{c}\text { No difference } \\
\text { before and } \\
\text { after CPAP } \\
\text { treatment }\end{array}$ \\
\hline
\end{tabular}

Lattimore et al. [42] studied 10 patients with newly diagnosed untreated moderate to severe OSA (AHI $>15 / h$ ) under autoCPAP treatment for 3 months. Total cholesterol, LDL-C and HDL-C were all within normal limits before CPAP treatment. There were no significant changes in serum lipids after autoCPAP treatment, but this may be due, partly at least, to the small number of subjects.

Kitahara et al. [43] found that CPAP treatment had no significant effect on serum total cholesterol at 2 months and 4 months after initiation of CPAP in patients with OSA.
In a double blind randomised controlled trial of therapeutic and sham CPAP for 3 months in men with type 2 diabetes and OSA, West et al. [44] found no significant changes in any lipid parameter. No differences before and after treatment were noted in terms of total cholesterol, HDL-C, and TGs in either group.

Drager et al. [45] studied the lipid profile of 24 patients with severe OSA and mild dyslipidaemia, free of comorbidities who received either no treatment $(n=12)$ or CPAP $(n=12)$. No significant changes were observed in blood cholesterol, TGs, HDL-C, LDL-C in both groups, showing that effective 
treatment of OSA with CPAP for 4 months did not significantly improve the lipid profile. Patients and control subjects presented with high borderline levels of LDL-C.

In a randomised blinded crossover trial in 34 obese Caucasians with symptoms indicating OSA, Coughlin et al. [46] compared the effect of 6-week therapeutic vs sham CPAP on serum lipids. No change was observed in terms of lipids in either group. Specifically, in the therapeutic CPAP group, there was no significant change in cholesterol $(\mathrm{p}=0.07)$, TGs $(\mathrm{p}=0.33)$, HDL-C $(\mathrm{p}=0.15)$ and LDL-C $(\mathrm{p}=0.66)$ after CPAP treatment.

Li et al. [47] examined the effect of 90 days of CPAP treatment in 20 patients, with moderate to severe OSA, who received nasal CPAP treatment, lasting 6 to $8 \mathrm{~h}$ per night. Comparison before and after CPAP treatment showed no significant changes in blood cholesterol, LDLC, HDL-C and TGs.

\section{EFFECT OF CPAP ON SERUM LIPIDS: CURRENT SITUATION AND IMPLICATIONS FOR FURTHER RESEARCH}

Current evidence suggests that CPAP may exert a beneficial effect on lipid profile in patients with OSA. However, this effect is not definitely proven. Indeed, there is data indicating that CPAP may fail to produce favourable changes. Based on the positive studies, CPAP may reduce cholesterol levels in both patients with initial normal [34] and abnormal lipid levels [20]. In the former, CPAP may improve total cholesterol, TGs, HDL-C and reduce LDL-C levels. Importantly, favourable changes are observed only in OSA patients with sufficient adherence to CPAP treatment $[6,35]$. Nonetheless, negative studies question the aforementioned beneficial effects [39-47]. It must not escape our notice, though, that some of the studies may be criticised for their small sample size [39, 42] and their relatively short follow-up period [34, 46]. Other limitations of the studies are the poor patient adherence to treatment [29] and the missing information regarding diet or physical activity [20].

Clearly, the role of CPAP in the amelioration of serum lipids has not been defined. Results are rather conflicting, which may be explained by the differences in recruited populations, as well as in study design and endpoints. Indeed, some works have included dyslipidaemic patients with OSA, under medication or not, while others patients with normal baseline lipids levels. The differences in recruited population and baseline characteristics between the subjects of the studies may produce contrasting results. Endpoints have also been variable, including various parameters of lipid profile. Of greater significance, follow-up periods varied significantly, ranging from 1 month [34] to 1 year [37].

Hence, further research is necessary to re-examine the effect of CPAP on lipids and especially to compare the beneficial effect of CPAP with that of statin administration. The latter class of agents is the established treatment for hyperlipidaemia, while it is also increasingly being appreciated for its valuable pleiotropic effects [48]. It is important to define which patients stand to benefit and how long the duration of treatment is, in order to produce fa- vourable changes. Moreover, the magnitude of the effect needs to be re-evaluated in comparison with the initial health status of patients, their adherence, lipid lowering medication, diet and the weight changes. Two further issues to address would be the potential favourable effect of CPAP on weight and insulin sensitivity. Regrettably, these two parameters have largely been ignored in the studies included, and so it is difficult to determine whether any of the observed effects on lipids could be, at least partly, attributed to or mediated by such changes.

All aforementioned issues should be addressed by largescale randomised controlled trials. It is the authors' opinion that the accumulating evidence for a positive effect of CPAP on lipids is very promising and warrants careful investigation.

\section{CONCLUSIONS}

The potential benefit of CPAP treatment on the lipid profile is of interest. However, it still remains under debate, due to the largely inconsistent results from numerous studies, recruiting populations with different characteristics. This disparity is, partly at least, explained by the differences in studied populations, study design and primary outcomes. Such disparity frequently renders meaningful conclusions difficult, as already shown for the effect of CPAP on glucose metabolism [49]. Indeed, the major limitations of most studies on the effect on lipids are the short follow-up period and the fact that adherence to CPAP treatment, a newly recognised factor affecting CPAP efficacy $[50,51]$, was overlooked. Furthermore, the small size of the study samples, the diversity of the patients, the validity of the placebo treatment and the missing information about the physical activities of the subjects may weaken study results. Hence, there is a clear need for large-scale randomised, controlled studies with better adherence to therapy and long-term follow-up, which will allow a definite conclusion regarding the effect of CPAP on the lipid profile. Such interventional studies will provide an answer to the question whether OSA is responsible for alterations in the lipid profile. In the meantime, CPAP still remains the established treatment for OSA and future research may, possibly, confirm an additional beneficial effect on lipids.

\section{DECLARATION OF INTEREST}

None

\section{ABBREVIATIONS}

AHI $=$ Apnoea-hypopnoea index
Apo $=$ Apolipoprotein
BMI $=$ Body mass index
CPAP $=$ Continuous positive airway pressure
EDS $=$ Excessive daytime sleepiness
ESS $=$ Epworth sleepiness scale
HDL-C $=$ High-density lipoprotein cholesterol
IH $=$ Intermittent hypoxia
LDL-C $=$ Low-density lipoprotein cholesterol
MetS $=$ Obtabolic syndrome
OSA $=$ Obstructive sleep apnoea




$$
\begin{array}{ll}
\text { PSG } & =\text { Polysomnography } \\
\text { RDI } & =\text { Respiratory disturbance index } \\
\text { TG } & =\text { Triglycerides }
\end{array}
$$

\section{ACKNOWLEDGEMENT}

None declared.

\section{REFERENCES}

[1] Punjabi NM. The epidemiology of adult obstructive sleep apnea. Proc Am Thorac Soc 2008; 5: 136-43.

[2] McNicholas WT, Bonsignore MR. Sleep apnoea as an independent risk factor for cardiovascular disease: current evidence, basic mechanisms and research priorities. Eur Respir J 2007; 29: 156-78.

[3] Malhotra A, Ayas NT, Epstein LJ. The art and science of continuous positive airway pressure therapy in obstructive sleep apnea. Curr Opin Pulm Med 2000; 6: 490-5.

[4] Giles TL, Lasserson TJ, Smith BH, White J, Wright J, Cates CJ. Continuous positive airways pressure for obstructive sleep apnoea in adults. Cochrane Database Syst Rev 2006; 3: CD001106.

[5] Gordon P, Sanders MH. Sleep.7: positive airway pressure therapy for obstructive sleep apnoea/hypopnoea syndrome. Thorax 2005; 60: 68-75

[6] Steiropoulos P, Tsara V, Nena E, et al. Effect of continuous positive airway pressure treatment on serum cardiovascular risk factors in patients with obstructive sleep apnea-hypopnea syndrome. Chest 2007; 132: 843-51.

[7] Steiropoulos P, Kotsianidis I, Nena E, et al. Long-term effect of continuous positive airway pressure therapy on inflammation markers of patients with obstructive sleep apnea syndrome. Sleep 2009; 32: 537-43.

[8] Weaver TE, Kribbs NB, Pack AI, et al. Night-to-night variability in CPAP use over the first three months of treatment. Sleep 1997; 20: 278-83.

[9] Zimmerman ME, Arnedt JT, Stanchina M, Millman RP, Aloia MS. Normalization of memory performance and positive airway pressure adherence in memory-impaired patients with obstructive sleep apnea. Chest 2006; 130: 1772-8.

[10] Hedner J, Darpo B, Ejnell H, Carlson J, Caidahl K. Reduction in sympathetic activity after long-term CPAP treatment in sleep apnoea: cardiovascular implications. Eur Respir J 1995; 8: 222-9.

[11] Jenkinson C, Davies RJ, Mullins R, Stradling JR. Comparison of therapeutic and subtherapeutic nasal continuous positive airway pressure for obstructive sleep apnoea: a randomised prospective parallel trial. Lancet 1999; 353: 2100-5.

[12] Katcher HI, Hill AM, Lanford JL, Yoo JS, Kris-Etherton PM. Lifestyle approaches and dietary strategies to lower LDLcholesterol and triglycerides and raise HDL-cholesterol. Endocrinol Metab Clin North Am 2009; 38: 45-78.

[13] Leren P, Foss PO, Helgeland A, Hjermann I, Holme I, LundLarsen PG. Effect of propranolol and prazosin on blood lipids. The Oslo Study. Lancet 1980; 2: 2-4.

[14] Lowenstein J. Effects of prazosi $\mathrm{n}$ on serum lipids in patients with essential hypertension: a review of the findings presented at the Satellite Symposium on coronary heart disease, hypertension and other risk factors, Milan. Am J Cardiol 1984; 53: 21A-23A.

[15] Lévy P, Bonsignore MR, Eckel J. Sleep, sleep-disordered breathing and metabolic consequences. Eur Respir J 2009; 34: 243-60.

[16] Li J, Thorne LN, Punjabi NM, et al. Intermittent hypoxia induces hyperlipidemia in lean mice. Circ Res 2005; 97: 698-706.

[17] Li J, Savransky V, Nanayakkara A, Smith PL, O’Donnell CP, Polotsky VY. Hyperlipidemia and lipid peroxidation are dependent on the severity of chronic intermittent hypoxia. J Appl Physiol 2007; 102: 557-63.

[18] Li J, Grigoryev DN, Ye SQ, et al. Chronic intermittent hypoxia upregulates genes of lipid biosynthesis in obese mice. J Appl Physiol 2005; 99: 1643-8.

[19] Kono M, Tatsumi K, Saibara T, et al. Obstructive sleep apnea syndrome is associated with some components of metabolic syndrome. Chest 2007; 131: 1387-92.
[20] Börgel J, Sanner BM, Bittlinsky A, et al. Obstructive sleep apnoea and its therapy influence high-density lipoprotein cholesterol serum levels. Eur Respir J 2006; 27: 121-7.

[21] Can M, Açikgöz S, Mungan G, et al. Serum cardiovascular risk factors in obstructive sleep apnea. Chest 2006; 129: 233-7.

[22] Iesato K, Tatsumi K, Saibara T, et al. Decreased lipoprotein lipase in obstructive sleep apnea syndrome. Circ J 2007; 71: 1293-8.

[23] Tan KC, Chow WS, Lam JC, et al. HDL dysfunction in obstructive sleep apnea. Atherosclerosis 2006; 184: 377-82.

[24] Newman AB, Nieto FJ, Guidry U, et al. Relation of sleep-disordered breathing to cardiovascular disease risk factors: the Sleep Heart Health Study. Am J Epidemiol 2001; 154: 50-9.

[25] Gruber A, Horwood F, Sithole J, Ali NJ, Idris I. Obstructive sleep apnoea is independently associated with the metabolic syndrome but not insulin resistance state. Cardiovasc Diabetol 2006; 5: 22.

[26] Zgierska A, Górecka D, Radzikowska M, et al. Obstructive sleep apnea and risk factors for coronary artery disease. Pneumonol Alergol Pol 2000; 68: 238-46.

[27] Coughlin SR, Mawdsley L, Mugarza JA, Calverley PM, Wilding JP. Obstructive sleep apnoea is independently associated with an in creased prevalence of metabolic syndrome. Eur Heart J 2004; 25 : 735-41.

[28] Kiely JL, McNicholas WT. Cardiovascular risk factors in patients with obstructive sleep apnoea syndrome. Eur Respir J 2000; 16: 128-33.

[29] Ip MS, Lam KS, Ho C, Tsang KW, Lam W. Serum leptin and vascular risk factors in obstructive sleep apnea. Chest 2000; 118: 580-6.

[30] McArdle N, Hillman D, Beilin L, Watts G. Metabolic risk factors for vascular disease in obstructive sleep apnea: a matched controlled study. Am J Respir Crit Care Med 2007; 175: 190-5.

[31] Sharma SK, Kumpawat S, Goel A, Banga A, Ramakrishnan L, Chaturvedi P. Obesity, and not obstructive sleep apnea, is responsible for metabolic abnormalities in a cohort with sleep-disordered breathing. Sleep Med 2007; 8: 12-7.

[32] Chin K, Shimizu K, Nakamura T, et al. Changes in intra-abdominal visceral fat and serum leptin levels in patients with obstructive sleep apnea syndrome following nasal continuous positive airway pressure therapy. Circulation 1999; 100: 706-12.

[33] Buechner NJ, Zidek W, Eer M, Haske M, Sanner BM. Obstructive sleep apnea syndrome. Effects of therapy on dyslipidemia. Somnologie 2001; 5: 97-102.

[34] Robinson GV, Pepperell JC, Segal HC, Davies RJ, Stradling JR. Circulating cardiovascular risk factors in obstructive sleep apnoea: data from randomised controlled trials. Thorax 2004; 59: 777-82.

[35] Dorkova Z, Petrasova D, Molcanyiova A, Popovnakova M, Tkacova R. Effects of continuous positive airway pressure on cardiovascular risk profile in patients with severe obstructive sleep apnea and metabolic syndrome. Chest 2008; 134: 686-92.

[36] Barceló A, Barbé F, de la Peña $\mathrm{M}$, et al. Insulin resistance and daytime sleepiness in patients with sleep apnoea. Thorax 2008; 63: 946-50.

[37] Oktay B, Akbal E, Firat H, Ardiç S, Kizilgun M. CPAP treatment in the coexistence of obstructive sleep apnea syndrome and metabolic syndrome, results of one year follow up. Acta Clin Belg 2009; 64: 329-34.

[38] Cuhadaroglu C, Utkusavas A, Ozturk L, Salman S, Ece T. Effects of nasal CPAP treatment on insulin resistance, lipid profile, and plasma leptin in sleep apnea. Lung 2009; 187: 75-81.

[39] Davies RJ, Turner R, Crosby J, Stradling JR. Plasma insulin and lipid levels in untreated obstructive sleep apnoea and snoring; their comparison with matched controls and response to treatment. J Sleep Res 1994; 3: 180-5.

[40] Barceló A, Barbé F, Llompart E, et al. Effects of obesity on Creactive protein level and metabolic disturbances in male patients with obstructive sleep apnea. Am J Med 2004; 117: 118-21.

[41] Al-Shaer M, Shammas N, Lemke J, et al. CPAP does not reduce high-sensitivity $\mathrm{C}$-Reactive protein in patients with coronary artery disease and obstructive sleep apnea. Int J Angiol 2005; 129-32.

[42] Lattimore JL, Wilcox I, Skilton M, Langenfeld M, Celermajer DS. Treatment of obstructive sleep apnoea leads to improved microvascular endothelial function in the systemic circulation. Thorax 2006; 61: 491-5.

[43] Kitahara Y, Hattori N, Yokoyama A, Nakajima M, Kohno N. Effect of CPAP on brachial-ankle pulse wave velocity in patients with OSAHS: an open-labelled study. Respir Med 2006; 100: 2160-9. 
[44] West SD, Nicoll DJ, Wallace TM, Matthews DR, Stradling JR. Effect of CPAP on insulin resistance and $\mathrm{HbAlc}$ in men with obstructive sleep apnoea and type 2 diabetes. Thorax 2007; 62: 969-74.

[45] Drager LF, Bortolotto LA, Figueiredo AC, Krieger EM, Lorenzi GF. Effects of continuous positive airway pressure on early signs of atherosclerosis in obstructive sleep apnea. Am J Respir Crit Care Med 2007; 176: 706-12.

[46] Coughlin SR, Mawdsley L, Mugarza JA, Wilding JP, Calverley PM. Cardiovascular and metabolic effects of CPAP in obese males with OSA. Eur Respir J 2007; 29: 720-7.

[47] Li C, Zhang XL, Liu H, Wang ZG, Yin KS. Association among plasma interleukin-18 levels, carotid intima-media thickness and severity of obstructive sleep apnea. Chin Med J (Engl) 2009; 122: $24-9$.
[48] Athyros VG, Kakafika AI, Tziomalos K, Karagiannis A, Mikhailidis DP. Pleiotropic effects of statins- clinical evidence. Curr Pharm Des 2009; 15: 479-89.

[49] Steiropoulos P, Papanas N, Nena E, Maltezos E, Bouros D. Continuous positive airway pressure treatment in patients with sleep apnoea: does it really improve glucose metabolism? Curr Diabetes Rev 2010; 6: 156-66.

[50] Steiropoulos P, Papanas N, Nena E, et al. Markers of glycemic control and insulin resistance in non-diabetic patients with Obstructive Sleep Apnea Hypopnea Syndrome: does adherence to CPAP treatment improve glycemic control? Sleep Med 2009; 10: 887-91.

[51] Steiropoulos P, Papanas N, Maltezos E, Bouros D. Is there a metabolic effect of continuous positive airway pressure in sleep apnoea? Adherence should not be underestimated. Eur Respir J 2009; 34 1209-10.

(C) Michailidis et al.; Licensee Bentham Open.

This is an open access article licensed under the terms of the Creative Commons Attribution Non-Commercial License (http://creativecommons.org/licenses/ by-nc/3.0/) which permits unrestricted, non-commercial use, distribution and reproduction in any medium, provided the work is properly cited. 